\title{
GALNT12 Gene
}

National Cancer Institute

\section{Source}

National Cancer Institute. GALNT12 Gene. NCI Thesaurus. Code C151996.

This gene plays a role in O-linked protein glycosylation. 